\title{
DETERMINATION OF THE RELATIONSHIP BETWEEN NON-PERFORMING LOANS AND PROFITABILITY IN THE TURKISH BANKING SYSTEM WITH PANEL REGRESSION ANALYSIS
}

\author{
DOI: 10.17261/Pressacademia.2021.1478 \\ PAP- V.14-2021(4)-p.14-19
}

\section{Aysegul Berrak Koten}

Istanbul Kultur University, Vocational School, Banking and Insurance Program, Istanbul, Turkey. a.koten@iku.edu.tr, ORCID: 0000-0002-5680-9920

\section{To cite this document}

Koten, A.B., (2021). Determination of the relationship between non-performing loans and profitability in the Turkish banking system with panel regression analysis. PressAcademia Procedia (PAP), 14, 14-19.

Permanent link to this document: http://doi.org/10.17261/Pressacademia.2021.1478

Copyright: Published by PressAcademia and limited licensed re-use rights only.

\section{ABSTRACT}

Purpose - The purpose of this study is to determine the effect of non-performing loans on profitability for public and private banks in the Turkish banking system with the help of panel regression analysis.

Methodology - In this study, the effect of Non-Performing Loans/Total Loans and Loan/Deposit Ratio on the Return on Assets for the period 2010.Q1-2020.Q4 for 3 public, 8 private, and 16 foreign capital banks in the banking system was determined by panel regression analysis. For the first-order stationary data, the Fixed Effects Model was found to be suitable as a result of the Hausman test, and the Greene heteroscedasticity test and the Wooldridge autocorrelation test were analyzed to provide the assumptions.

Findings - As a result of the analysis, a statistically significant relationship was determined in the direction of decreasing the Non-Performing Loans/Total Loans ratio by $23 \%$ in the Return on Assets. On the other hand, the Loan/Deposit Ratio is statistically significantly correlated with the Return on Assets by $11.5 \%$. In this study, it has been revealed that the profitability of a bank with increasing non-performing loans will decrease.

Conclusion - Return on assets is an important indicator that shows how much profit the bank management can generate with current assets and how effectively the assets are used. One of the important factors reducing profitability is the increase in non-performing loans. For this reason, for banks to increase their market share, they must collect more effectively and make more accurate decisions while giving loans. It is obvious that banks and regulatory and rule-making institutions must act in accordance with these results when determining their strategy. Since it is important in terms of showing the solvency of borrowers in an economy, the risk level, and the asset quality of banks, there is a need for estimations on the subject of non-performing loans analyzed with different methods in the literature.

Keywords: Non-performing loans, profitability, Turkish banking system, panel regression analysis JEL Codes: G21, G32, C51

\section{INTRODUCTION}

In the financial sector, the balance is realized through banks in the fund market, which is formed by those who supply funds and those who demand funds. Developments in the financial sector show important results in the real sector, directly and indirectly (Panta, 2018: 152). The progression of non-performing loans; however, affects the economy on a micro and macro scale (Laryea et al., 2016: 463). Banks face some risks when they perform their funding functions. In our present day, the competitive advantage of banks depends on how they manage these risks instead of material and financial resources. One of these risks is credit risk (Radivojevic \& Jovovic, 2017: 301).

There are many internal and external factors causing a loan to become non-performing. Risks that stem from non-performing loans mainly manifest themselves in external economic developments such as economic depression (Do et al., 2020: 374). For example, NPL figures increased rapidly with the 2001 financial crisis in Turkey, and the share of non-performing loans in total loans reached $19 \%$ In 2002 . The measures that were taken later enabled this figure to fall back to single digits (Taskin, 2011: 290). Non-performing loans make up an important issue for policymakers who try to stabilize the financial system and the macroeconomy. The Non-Performing Loans ratio comes to the forefront as the measure of credit risk and asset quality for the banking sector (Kingu et al., 2018: 72). This ratio is a preliminary indicator for risks such as decreased future cash flows of banks, duration problems that may emerge between the receivables and liabilities with late collection, and the increased costs that stem from the collection of receivables through legal means (Akter \& Roy, 2017: 128). The nonperforming loans ratio is an asset quality indicator showing the income-generating quality of the loans reported in the assets of the bank (Cucinelli, 2015: 62).

Increases in the non-performing loans ratio affect the liquidity of banks negatively and often bring with them bank failures (Christaria \& Kurnia, 2016: 45). However, the total cost of problematic loans is not limited to bank failures. As the NPL ratio of banks increases, banks have 
to increase their own funds as a precaution for problematic loans under the assumption that loans cannot be paid (Mileris, 2012: 498; Skarica, 2013: 38; Zhang et al., 2016: 52). As a result, the credit amount provided by banks decreases. The decrease in the amount of money in the market raises the interest rates limiting the financing opportunities that are needed for economic growth. For this reason, the increase in non-performing loans causes a contractionary pressure on the economy.

The negative effects of the increased non-performing loans on the financial system and macroeconomics made them become an important issue to be resolved especially after the global economic crisis (Anastasiou, 2016: 119). The policies and measures that must be taken by policymakers and decision-makers in the financial system to resolve this problem depend on the factors which affect non-performing loans or the determinants of non-performing loans negatively. For this reason, the main purpose of the study was to determine the effects of nonperforming loans on profitability for banks that operate in Turkey.

\section{LITERATURE REVIEW}

Some studies in the literature conducted on non-performing loans are as follows:

Hu et al. (2004), observed in Taiwan in the 1996-1999 period that the relations between bank scale and non-performing loans were negative; non-performing loans decreased in parallel with the increase in the public share in the bank, and non-performing loans also decreased after deregulation.

In the study that was conducted by Gungor (2007), it was found that the share of non-performing loans in total loans decreased the profitability in all domestic and foreign banks. It was also found that it affects ROE negatively, as in ROA.

In the study conducted by Lin and Sum (2012), banks in Taiwan were examined in the 1997-2010 period, and it was found that the NPL ratios of banks increased during the election periods. This finding is important in terms of revealing the effects of political practices on bank performance.

It was observed in the study of Vatansever and Hepsen (2013) that the variables of ROE and capital adequacy affected the non-performing loan ratios in banks in Turkey positively in the 2007.Q1 - 2013.Q3 period.

Klein (2013) found that there was a negative relation between ROA and non-performing loans in his study conducted in Central, Eastern, and Southeastern European countries.

Erdinc and Abazi (2014); however, examined the banks in 20 developing European countries for the 2000-2011 period, and found that the bank foreign ownership ratio variable did not have significant effects on non-performing loans.

Yagcilar and Demir (2015) revealed that foreign banks, capital adequacy ratio, and non-performing loans were related positively to foreign banks, the scale and ROA variables were in a negative relation with NPLs in Turkey in the 2002.Q4 - 2013.Q3 period, and the credit risks of foreign banks were higher than domestic banks.

In the study that was conducted by Dimitrios et al. (2016) with Euro area data for the period 1990.Q1 - 2015.Q3, it was found that Return on Assets (ROA) and Return on Equity (ROE), which are used as profitability variables, were related to non-performing loans negatively.

In their study, Abdioglu and Aytekin (2016) reported that the NPL ratio, net interest margin, capital adequacy, and solvency ratio had negative impacts on the non-performing loans of banks in the previous period in Turkey (2002-2014). It was also found in the same study that high loan growth decreased the non-performing loan rates; and reported that the literature results showed that there was a strong relationship between variables such as capital adequacy ratio, non-performing loan ratio of the previous year, return on equity, and non-performing loans, and also, bank profitability decreased non-performing loan rates.

Radivojevic and Jovovic (2017) examined the determinants of NPL ratio using a cross-country analysis from the sample of 25 emerging countries. Using the panel data approach, determinants of NPL are analyzed for the period from 2000 to 2011 . The results show that NPLs rates can be mainly explained by crucial macroeconomic factors, such as the GDP and inflation rate, and bank-specific factors, such as ROA, CAP, and lagged NPLs rates.

Rachman et al. (2018) examined various banking factors that affected the NPLs in Indonesia and concluded that the high profitability of banks has lower NPLs due to their better advancing activity and effective credit supervision system.

Psaila et al. (2019) used panel data for 2013-2017 from annual reports of the 35 listed commercial banks in the Euro-Mediterranean region. Findings show that there is a negative impact of NPLs on ROA, indicating that problematic loans negatively impact listed commercial banks' profitability in the Euro-Mediterranean region.

Collaku and Aliu (2021) showed that the effect of nonperforming loans on profitability is statistically significant and shows that for each $1 \%$ increase in NPL, the Return of Assets decreases by $0.19 \%$, holding other variables constant.

\section{DATA AND METHODOLOGY}

\subsection{Methodology}

In the present study, the effects of Non-Performing Loans/Total Loans and Loan/Deposit Ratios on the return on assets were determined with the panel regression analysis for the period 2010.Q1-2020.Q4 for 3 public capital, 8 private capital, and 16 foreign capital banks in the banking system. Panel data estimation methods are performed with pooled, fixed, and random effects. Pre-tests are required to determine 
which method to choose (Baltagi, 2005: 78). Chow and Breush-Pagan (BP) tests were used in the first stage, and $\mathrm{H}_{\circ}$ was rejected for the panel regression estimation process. In the other stage, the fixed effects model (SEM) was decided by applying the Hausman test. Also, when this model was analyzed, different solution algorithms were tried, and the "Cross-section SUR algorithm", which gives the smallest total squared error value, was used in the end. Cross-section dependency and homogeneity tests were performed prior to the panel data analysis, and it was determined as a result of the first and second-generation unit root tests that the variables were fixed I(1) for the first-order difference. In this way, the panel regression model was estimated by taking the first-order differences.

\subsection{Data}

The panel regression analysis was applied for 27 banks based on quarterly data for the 2010.01-2020.Q4 period. Investment and development banks were excluded from the sampling.

Table 1: The Variables Considered in Panel Regression

\begin{tabular}{|l|c|l|}
\hline Variables & Abbreviation & \multicolumn{1}{c|}{ Definition } \\
\hline Non-Performing Loans/Total Loans & NPL/TL & Independent Variable \\
\hline Loan/Deposit Ratio & L/DR & Control Variable \\
\hline Return on Assets & ROA & Dependent Variable \\
\hline
\end{tabular}

\subsection{Analysis and Results}

The fact that the variables were homogeneous/heterogeneous changes the form of the unit root and cointegration tests that will be applied (Hsiao, 2003: 56). Pesaran \& Yamagata (2008) and Pesaran et al. (2008) provided guidance on which one to use in first-generation unit root tests. On the other hand, if there is a cross-section dependency, it is necessary to apply second-generation unit root tests (Wooldridge, 2010: 67). In this study, the Berusch Pagan (1980) $C D_{\llcorner M 1}$ test was used because there were 27 banks ( $N=27$ ) and 44 quarter periods ( $\left.T=44\right)$, and the time dimension was larger than the cross-section dimension $(\mathrm{T}>\mathrm{N})$.

Table 2: Cross Section Dependency and Homogeneity Test Results

\begin{tabular}{|l|c|c|c|c|}
\hline Variables & $\begin{array}{c}\text { CD } \\
\text { Test Statistics }\end{array}$ & $\begin{array}{c}\text { LMadj } \\
\text { Test Statistics }\end{array}$ & $\begin{array}{c}\text { CD } \\
\text { p value }\end{array}$ & $\begin{array}{c}\text { LMadj } \\
\text { p value }\end{array}$ \\
\hline Non-Performing Loans/Total Loans & 8.551 & 8.990 & 0.000 & 0.001 \\
\hline Loan/Deposit Ratio & 6.908 & 7.325 & 0.000 & 0.000 \\
\hline Return on Assets & 10.417 & 10.942 & 0.000 & 0.000 \\
\hline $\begin{array}{l}\text { Coefficient Homogeneity Test } \\
\text { (Statistical Value) }\end{array}$ & \multicolumn{2}{|c|}{$\Delta=12.558$} & \multicolumn{2}{c|}{$\mathrm{p}=0.000$} \\
\cline { 2 - 5 } & \multicolumn{2}{|c|}{$\Delta$ adj $=16.208$} & \multicolumn{2}{c|}{$\mathrm{p}=0.00$} \\
\hline
\end{tabular}

Since the probability values of the test results were less than $5 \%$, the null hypothesis (the slope coefficients were homogeneous) was rejected, and it was determined that the coefficients were heterogeneous. Cross-section dependence was also determined between units ( $p<0.05$ ). First-generation unit root tests are divided into two as homogeneous and heterogeneous. As the coefficients were heterogeneous here, the first-generation unit root tests that were based on the heterogeneous model assumption, Im, Pesaran and Shin (2003), Maddala and Wu (1999), Choi (2001) were used.

Table 3: First-Generation Panel Unit Root Test Results

\begin{tabular}{|c|c|c|c|c|c|c|}
\hline \multirow{3}{*}{ Financial Ratios } & \multicolumn{2}{|c|}{ Maddala \& Wu Test } & \multicolumn{2}{|c|}{ Im, Pesaran \& Shin Test } & \multicolumn{2}{|c|}{ Choi Test } \\
\hline & Level & $\begin{array}{c}\text { 1st Level } \\
\text { Difference }\end{array}$ & Level & $\begin{array}{c}\text { 1st Level } \\
\text { Difference }\end{array}$ & Level & $\begin{array}{c}\text { 1st Level } \\
\text { Difference }\end{array}$ \\
\hline & Trend+Constant & Constant & Trend+Constant & Constant & Trend+Constant & Constant \\
\hline $\begin{array}{l}\text { Non-Performing } \\
\text { Loans/Total Loans }\end{array}$ & -1.215 & $-8.332 *$ & -1.046 & $-9.405^{*}$ & -1.360 & $-9.752 *$ \\
\hline Loan/Deposit Ratio & -1.673 & $-7.309 *$ & -1.721 & $-8.449 *$ & -1.548 & $-9.123 *$ \\
\hline Return on Assets & -0.983 & $-9.113^{*}$ & -1.147 & $-10.321^{*}$ & -1.202 & $-10.559 *$ \\
\hline
\end{tabular}

*Static variables for 0.05

It was found as a result of panel unit root tests that the variables were I (1) for the first-order difference, namely, were stationary. In such a case, the analysis is examined by taking first-order differences. If there is cross-section dependency in panel data, using second-generation unit root tests provides more consistent, efficient, and powerful estimations. Second-generation unit root tests must be used in the present study since cross-section dependence was found (Özel et al., 2013: 168). CADF, which is one of the second-generation unit root tests, was used. The results of the CADF Test that was developed by Pesaran (2007) are given in Table 4. 
(fields). If some of the loans extended by a bank fall under follow-up, it is obligatory to set aside a certain amount of special provisions in the scope of the relevant regulation, and the provisions are then recorded as losses in the balance sheet.

It can be argued that the lower the NPL ratio in a bank, the more successful its risk management is. The estimation of non-performing loans has great importance for risk management and stakeholders in the economy. In this context, studies that are based on observations and econometric models are required. The purpose of this study was to determine the effects of Non-Performing Loans/Total Loans and Loan/Deposit Ratio on the Return on Assets for the period 2010.Q1-2020.Q4 for 3 public capitals, 8 private capitals, and 16 foreign capital banks in the banking system with the panel regression analysis as a result of which it was found that when the Non-Performing Loans/Total Loans variable increased 1 unit, the ROA variable decreased 0.230 units, and when the Loan/Deposit Ratio increased 1 unit, the ROA variable increased 0.115 units. In this way, it was found that non-performing loans had a decreasing effect on the return on assets in the Turkish banking system in parallel with many studies in the literature.

Although many factors affect the non-performing status of a loan, the main reason is the unpredictable decrease in the income of the borrower because of internal/external reasons that stem from the general economy. The supply and demand for loans contract during periods of economic recession, and the problem of non-repayment of existing loans may arise. Also, the rapid growth of enterprises based on incorrect high risks, the operational failures of the company, etc. because of internal reasons and repayment problems may arise regarding the loans. However, some operational problems weakening the collection capability of the bank may also cause that the loans fall into nonperforming status. A crisis in the economy will increase the non-performing loans rapidly in a short time causing a domino effect from banks to other sectors with its leverage characteristics in a condition in which the loan portfolio is not well-structured. Non-performing loans, which show the asset quality of the financial sector in an economy, and the debt repayment capacity of the households and the real sector, are the leading risk indicators for the real economy. Non-performing loans are often used as the indicators of predicting bank failures increasing the funding costs of the affected bank when compared to their peers. Deterioration of the credit quality undermines the ability of the banking system in providing loans, which, in return, causes financial stability problems and decreased economic activity.

In future studies, analyzes that will examine the effects of non-performing loans on other bank-specific determinants which cover different periods and sampling can be conducted. Non-performing receivables will be required in banking due to various reasons. However, efforts must be made to decrease the amount of non-performing loans, and more effective solutions must be offered.

\section{REFERENCES}

Abdioğlu, N., \& Aytekin, S. (2016). Takipteki kredi oranını etkileyen faktörlerin belirlenmesi: Mevduat bankaları üzerinde bir dinamik panel veri uygulanması. İ̧̧letme Araştırmaları Dergisi, 8(1), 538-555.

Akter, R., \& Roy, J.K. (2017). Non-performing loan on profitability: Evidence from banking sector of Dhaka Stock Exchange. International Journal of Economics and Finance, 9(3), 126-132.

Anastasiou, D., Louri, H., \& Tsionas, M.E. (2016). Determinants of non-performing loans: Evidence from Euro-area countries. Finance Research Letters, 18(1), 116-119.

Baltagi, B. H. (2005). Econometric Analysis of Panel Data. 3rd edition. West Sussex: John Wiley \& Sons Ltd.

Bayar Y. \& Sezgin H. F. (2017). Trade openness, inequality and poverty in Latin American countries. Ekonomika (Economics), 96(1), $47-57$.

Christaria, F. \& Kurnia, R. (2016). The impact of financial ratios, operational efficiency and non-performing loan towards commercial bank profitability. Accounting and Finance Review (AFR), 1(1), 43-50.

Choi, I. (2001). Unit root tests for panel data. Journal of International Money and Finance, 20(2), 249-272.

Cucinelli, D. (2015). The impact of non-performing loans on bank lending behavior: Evidence from the Italian banking sector. Eurasian Journal of Business and Economics, 8(16), 59-71.

Collaku, B. \& Aliu, M. (2021). Impact of non-performing loans on bank's profitability: Empirical evidence from commercial banks in Kosovo. Journal of Accounting, Finance and Auditing Studies, 7(3), 226-242.

Dimitrios, A., Helen, L., \& Mike, T. (2016). Determinants of non-performing loans: evidence from Euro-Area countries. Finance Research Letters, 18 (1), 116-119.

Do, H., Ngo, T., \& Phung, Q. (2020). The effect of non-performing loans on profitability of commercial banks: Case of Vietnam. Accounting, 6(3): 373-386.

Erdinc, D., \& Abazi, E. (2014). The determinants of NPLs in emerging Europe. Journal of Economics and Political Economy, 1(2), $112-125$.

Gungor, B. (2007). Türkiye'de faaliyet gösteren yerel ve yabancı bankaların kârlılık seviyelerini etkileyen faktörler: Panel veri analizi. İktisat İşletme ve Finans, 258(22), 40-63.

Hsiao, C. (2003). Analysis of Panel Data. (2nd ed., Econometric Society Monographs). Cambridge: Cambridge University Press.

Hu, J.-L., Li, Y., \& Chiu, Y-H. (2004). Ownership and non performing loans: Evidence from Taiwan's banks. The Devaloping Economies, 42(3), 405-420.

Im, K. S., Pesaran, M. H., \& Shin, Y. (2003). Testing for unit roots in heterogeneous panels. Journal of Econometrics, 115(1), 53-74. 
Kingu, P. S., Macha, S., \& Gwahula, R. (2018). Impact of non-performing loans on bank's profitability: Empirical evidence from commercial banks in Tanzania. International Journal of Scientific Research and Management, 6(1), 71-78.

Klein, N. (2013). Non performing loans cesee: Determinants and impact on macroeconomic performance. IMF Working Paper, 13 (72), 1-27.

Maddala, G. S. \& Wu, S. (1999). A comparative study of unit root tests with panel data and a new simple test. Oxford Bulletin of Economics and Statistics, Special Issue, 61(1), 631-652.

Laryea, E., Ntow-Gyamfi, M., \& Alu, A. A. (2016). Nonperforming loans and bank profitability: Evidence from an emerging market. African Journal of Economic and Management Studies, 7(4), 462-481.

Lin, J. C. \& Sum, V. (2012). bank ownership and performance in Taiwan: Do politics matter? Journal of Finance and Accountancy, 10(1), 1230 .

Mileris, R. (2012). Macroeconomic determinants of loan portfolio credit risk in banks. Ekonomika-Engineering Economics, 23(5), $496-504$.

Ozel, H. A., Sezgin, F. H. \& Topkaya, O. (2013). Investigation, of economic growth and unemployment relationship for G7 countries using panel regression analysis. International Journal of Business and Social Science, 4(6), 162-170.

Panta, B. (2018). Non-performing loans and bank profitability: Study of joint venture banks in Nepal. International Journal of Sciences: Basic and Applied Research (IJSBAR), 42(1), 151-156.

Pesaran, M. H. (2004). General diagnostic tests for cross section dependence in panels. CESifo Working Papers, No. 1229, 1-40.

Pesaran, M. H. (2007). A simple panel unit root test in the presence of cross-section dependence. Journal of Applied Econometrics, 22(2), 265-312.

Pesaran, M. H. \& Yamagata, T. (2008). Testing slope homogeneity in large panels. Journal of Econometrics, 142 (1), $50-93$.

Pesaran, M. H., Ullah A., \& Yamagata T. (2008). A bias-adjusted LM test of error cross-section independence. Econometrics Journal, 11(1), 105-127.

Psaila, A., Spiteri, J., Grima, S. (2019). The impact of non-performing loans on the profitability of listed Euro-Mediterranean commercial banks. International Journal of Economics and Business Administration, 6(4), 166-196.

Rachman, R.A., Kadarusman, Y.B., Anggriono, K. and Setiadi, R. (2018). Bank- specific factors affecting non-performing loans in developing countries: Case study of Indonesia. The Journal of Asian Finance, Economics and Business (JAFEB), 5(2), 35-42.

Radivojevic, N., \& Jovovic, J. (2017). Examining of determinants of non-performing loan. Prague Economic Papers, 26(3), 300-316.

Skarica, B. (2013). Determinants of non-performing loans in central and eastern European countries. Financial Theory and Practice, 38(1), 3759

Taskin, F. D. (2011). Türkiye'de ticari bankaların perfonmasını etkileyen faktörler. Ege Akademik Bakış, 11(2), $289-298$.

Wooldridge, J. M. (2010). Econometric Analysis of Cross Section and Panel Data. 2nd edition. Cambridge, Massachusetts, London, England: The MIT Press.

Vatansever, M. \& Hepsen, A. (2013). Determining impacts on non-performing loan ratio in Turkey. Journal of Finance and Investment Analysis, 2(4), 119-129.

Yagcilar, G. G., \& Demir, S. (2015). Türk bankacılık sektöründe takipteki kredi oranları üzerinde etkili olan faktörlerin belirlenmesi. Uluslararası Alanya İşletme Fakültesi Dergisi, 7(1), 221-229.

Zhang, D., Cai, J., Dickinson, D. \& Kutan, A. (2016). Non-performing loans, moral hazard and regulation of the Chinese commercial banking system. Journal of Banking \& Finance, 63(1), 48-60. 